\title{
What is theory?
}

\author{
Jon Nixon \\ University of Sheffield, UK. Head of School of Education \\ 388 Glossop Road, Sheffield S10 2JA, UK \\ j.nixon@sheffield.ac.uk
}

\section{Resum}

Aquest article explora la relació entre teoria i pràctica a través d'una sèrie de qüestions relacionades entre si. Es planteja que la pràctica professional, el pensament humà i l'enteniment teòric es relacionen dinàmicament en cada intent seriós de desenvolupament professional. Un dels objectius de l'article és reunir diferents fils argumentals dels meus recents escrits sobre la natura canviant del professionalisme a través d'una diversitat de grups ocupacionals, tant en el sector públic com en el dels serveis sense ànim de lucre, d'aquí les referències als meus propis escrits acadèmics sobre el tema.

He tractat de seguir un estil informal d'acord amb l'origen de l'article, arran de les enriquidores converses que es van derivar del summament interessant seminari que va tenir lloc a la Universitat Autònoma de Barcelona (UAB) a l'octubre del 2003.

Paraules clau: teoria i pràctica, pràctica professional, desenvolupament professional, natura canviant del professionalisme, sectors públic i de serveis.

\section{Abstract}

This paper explores the relation between theory and practice through a series of linked questions. It argues that professional practice, human thoughtfulness and theoretical understanding are in dynamic interplay in any serious attempt at professional development. One of the purposes of the paper is to draw together various strands of my own recent writing on the changing nature of professionalism across a variety of occupational groups within the public and non profit-making sectors - hence the references to some of my own academic writing in this area. I have tried to adopt an informal style that seems appropriate to the origins of the paper in the highly engaging seminar and rich conversations held at the Universitat Autònoma de Barcelona (UAB) in October 2003.

Key words: theory and practice, professional practice, professional development, changing nature of professionalism, public and non profit-making sectors.

\section{Resumen}

Este artículo explora la relación entre teoría y práctica a través de una serie de cuestiones relacionadas entre sí. Se plantea que la práctica profesional, el pensamiento humano y el entendimiento teórico se relacionan dinámicamente en cada intento serio de desarrollo profesional. Uno de los objetivos del artículo es reunir diferentes hilos argumentales de mis recientes escritos sobre la naturaleza cambiante del profesionalismo a través de una diver- 
sidad de grupos ocupacionales, tanto en el sector público como en el de los servicios sin ánimo de lucro, de ahí las referencias a mis propios escritos académicos sobre el tema. He tratado de seguir un estilo informal acorde con el origen del artículo, a raíz de las enriquecedoras conversaciones que se derivaron del sumamente interesante seminario que tuvo lugar en la Universitat Autònoma de Barcelona (UAB) en octubre del 2003.

Palabras clave: teoría y práctica, práctica profesional, desarrollo profesional, naturaleza cambiante del profesionalismo, sector público y de servicios.

\section{Summary}

Introduction The public dimension of human

What characterises professional practice?

The complex, indeterminate nature of professional judgement

The social frame within which professional judgement is exercised

The morally purposeful nature of professional judgement thoughtfulness

The reflexive dimension of human thoughtfulness

What is theory in the context of professional understanding?

Conclusion

References

The deliberative dimension of human thoughtfulness

\section{Introduction}

What is theory? That's a very big and imposing question. It suggests, perhaps, that there is an abstract something called "theory» to which specific theories correspond and which can be defined independently of the contexts within which those specific theories are painstakingly developed; that if only we were able to access the black box of, say, Newton's theory of gravitational attraction, Darwin's theory of evolution through natural selection, or Rawls's theory of justice as fairness, we'd discover significant commonalities regardless of the actual scientific and scholarly practices underlying these theories. In its abstract simplicity the question, what is theory?, implies that the idea of theory somehow determines how in practice we theorise; how we do theory at precise points and within specific sectors.

I want to resist that implication and to argue that theory is shaped by practice and must be understood in terms of the relation between practice and thinking. I do not contribute to theory by first understanding what theory is and then developing a theory of my own. I do theory by developing collaborative models of thoughtful practice that challenge taken for granted assumptions and suggest new lines of enquiry; I do theory by learning how to align thoughtfulness and practice within specific contexts that require constant negotiation across complex professional, cultural and social boundaries. Theory is built upon the shared understandings that you or I manage to sustain across these demarcations. 
I am not here arguing against theory. What I am arguing against is the idea that practice can simply be read off from the grand narratives of theory or that our own grand theories can be imposed upon others. The process of theorising always involves thoughtful practice; thoughtful practice involves engaging with others; and engaging with others always involves the recognition of difference. There is no other way of doing it. However philosophers of science may define theory in the abstract, we know that, in practice, theorising involves the difficult art of arguing beyond the dead-end of disagreement to albeit provisional and sometimes risky modes of collaborative endeavour.

So, I shall attempt to work towards the question of "what is theory?» by addressing what I see as two prior questions: the question of what characterises professional practice and the question of how thoughtfulness relates to professional practice. My hope is that these prior deliberations will help clarify the relation between theory and practice and thereby enable us to locate the question, "what is theory?» in terms of our own professional concerns and orientations.

\section{What characterises professional practice?}

No science will relieve common sense, even if scientifically informed, of the task of forming a judgement. (Habermas, 2003, 108)

Within the last fifty years we have seen, within the UK, the rise of a predominantly professional society; the increase, that is, in the number of occupational groups claiming professional status. The tacit terms of the 1945 settlement were that professional autonomy would be granted in return for public service. Within this post $2^{\text {nd }}$ World War era, the public sector professional, espousing the values of professional autonomy and the public service ethic, established a gold standard. That standard, however, was severely shaken by the economic and political turbulence of the 1970's and effectively toppled by the market-driven policies of the Thatcherite and post-Thatcherite era: policies that replaced the model of public sector professionalism and its ethic of public service with a model of private sector managerial professionalism and its ethic of private entrepreneurialism (see Nixon et.al., 1997, and Perkin, 1989 , for an elaboration of this argument).

This is not the place to rehearse that history in detail, although its legacy is still being worked through. What is clear is that sometime in the backend of the $20^{\text {th }}$ Century the public service ethic became estranged from the notion of professionalism and that the trade-off between the public service ethic and professional autonomy gave way to bureaucratic accountability. Government, and indeed society, is requiring of professionals a different kind of rationale. What does this new professionalism look like? How should it stake its claim? What are its moral bases? These kinds of questions, I believe, have to be addressed before we can progress to the more difficult question of what theory might mean in relation to such a profession. 
The claim of any occupational group to professional status is based upon its capacity to make informed and authoritative judgements regarding the adequacy of the available evidence, the provenance of that evidence, and the options available in the light of that evidence. Judgement is paramount. In defining the key characteristics of professional practice, we need therefore to look more closely at what constitutes judgement and how judgement informs decision.

\section{The complex, indeterminate nature of professional judgement}

Judgements do not come ready made: they cannot simply be read off from evidence. They requires the tacit or personal knowledge of whoever is making the judgement. The notion of wisdom is often attached to judgement precisely because it makes this necessary connection between the evidence upon which judgement is based and the tacit knowledge which the professional brings to bear upon that evidence. This does not mean that professional judgement should not be brought to account, but that the accounts professionals give regarding their judgements are likely to be counter-intuitive and, indeed, sometimes counter-factual.

Judgement is not, in other words, a matter of pronouncing that $1+1=2$. Professionals, of course, routinely deal in such simple equations, but their true professionalism comes into play at precisely those points where the simple arithmetic breaks down and finer judgements have to be made. Speak to any marriage guidance counselor about that simple equation, $1+1=2$ : they will tell you about the difficulties surrounding the notion of ' 1 -ness', in terms of identity, and the even greater difficulty of reducing two complex ' 1 -nesses' to a '2-ness', in terms of human relationship. Judgement is premised upon the capacity for deconstructive analysis.

Professional judgement, in other words, comes into play at precisely those points where the common sense guidelines are unclear and the criteria open to multiple interpretation. Judgement is always open to re-interpretation: in the light of emerging evidence, the re-interpretation of existing evidence, or simply the wisdom of hindsight. Professional judgement is a risky and unpredictable business.

\section{The social frame within which professional judgement is exercised}

So far I have referred to professional judgement as if it were an individualistic endeavour. This is misleading. Judgement is exercised in social and indeed often highly politicised contexts. To gain legitimacy professionals must engage with those contexts and seek to build agreement regarding the efficacy of their judgements. As a teacher, it is important that my students understand my judgement of their work, otherwise they cannot work with me to progress academically. As a patient, it is important that I understand my general practitioner's judgement of my condition, otherwise I 
cannot work with her to heal myself. Judgement, to be effective, must be dialogical.

Professionals, it has to be said, have not been very good at managing this social aspect of professional judgement. We have preferred to pronounce rather than to consult; to question rather than to listen; to speak rather than to hear. We have been prone to respond to symptoms, rather than to enquire into the physical pain and social suffering that may or may not give rise to those symptoms. In doing so, we have run the risk of imposing our own professional assumptions, rather than building a broader framework of public dialogue. Professional judgement has thereby too often become diminished and privatised.

To be effective professionals must, I believe, reach out to their publics. The problem with the old public service ethic was that it was too often based on the assumption that the professional knows best. Professional knowledge, however, relies crucially upon information and insights provided by those with whom professionals work: pupils, students, patients, families, parents, drug addicts, the traumatised, etc. Professional judgement may be the ultimate responsibility of the professional, but that professional responsibility can only be fulfilled by professionals who learn and listen. We need learning professions and listening institutions (see Nixon, 2003).

\section{The morally purposeful nature of professional judgement}

Professional judgement, in other words, is morally purposeful. Its ends and purposes prefigure a better, or at least more decent, society. Our judgements, regardless of our political persuasion, are driven by moral considerations: the desire to educate, to heal, to enlighten, to encourage, to unburden, to enthuse, etc. Without that ethical content our various professional occupations become devoid of their professionalism. To be professional is to acknowledge the moral dimension of one's occupation: to recognise that one has a moral career as well as just a career.

The virtues of professionalism vary across occupations, but what we might call the caring professions share a moral concern with the virtues of truthfulness (accuracy, sincerity), the virtues of respect (attentiveness, honesty) and the virtues of authenticity (courage, compassion). The moral content of professionalism focuses upon our learning to become accurate and sincere, attentive and honest, and courageous and compassionate. We fulfil the requirements of professionalism by initiating ourselves into these complicatedly inter-layered, virtuous dispositions.

Professional training - at both the levels of initial and continuing education- pays far too little attention, I believe, to the moral dimensions of professional practice. Bureaucratic accountability systems do little to help with their relentless emphasis on performativity and outcome measures. Somehow we have to reclaim a sense of moral purposefulness whereby, as professionals, we re-engage with our publics within an increasingly complex and sharply differentiated society (see Nixon, 2001a). 
How does thoughtfulness relate to professional practice?

I form an opinion by considering a given issue from different viewpoints, by making present to my mind the standpoint of those who are absent; that is, I represent them ... The more people's standpoints I have in mind while I am pondering a given issue, and the better I can imagine how I would feel and think if I were in their place, the stronger will be my capacity for representative thinking and the more valid my final conclusions, my opinions. (Arendt, $1968,241)$

Implicit in my argument so far has been the assumption that professional practice is not just about doing things, but about doing things thoughtfully. This raises the question of what I mean by thoughtfulness and of how thoughtfulness relates to professional practice. Traditionally, professionals have laid claim to specialist modes of thought, from which their publics have been largely excluded. I want to argue that thoughtfulness is ordinary: that when we, as professionals, are being thoughtful we are doing something that is not categorically different from what human beings generally are doing when they are thinking through their pain, their aspirations, their dilemmas, their hurts, their personal histories, etc. Thoughtfulness is a common resource.

Here I do want to import some grand theory. Not just to reinforce the point I made earlier that theory matters, but because I have learnt so much, and continue to learn so much, from this particular thinker. Hannah Arendt wrote about the human condition as she understood it; she wrote about the Eichman trials and the nature of evil, and she wrote about totalitarianism; she wrote about the possibility of goodness and the relation between goodness and democratic structures of governance. An abiding theme throughout her writings is the centrality of thoughtfulness in the complex process of human flourishing. She believed that within the common heritage of thought lie the resources of hope (see Arendt, 1967; 1998).

\section{The deliberative dimension of human thoughtfulness}

Arendt saw thoughtfulness as a common human resource. Thinking, she maintained, is not the privileged preserve of professional thinkers, but the common heritage of all thinking human beings. Crucially, she argued, it is a deliberative process whereby we move backwards and forwards between a consideration of ends and means in order to decide upon the best possible course of action.

This process of deliberation is not a matter of first setting goals and then devising the means of attaining those goals. It is a matter of tackling practical problems in such a way that both means and ends have to be thought through in relation to one another. Ends, in other words, are not independent of means; on the contrary, they are implicated in whatever means we employ. 
She argued that this, if you like, pragmatic mode of thought characterises human thoughtfulness. We devise tools which are extensions of ourselves and we use these tools to help us envisage future possibilities. These possibilities, however, only become imaginable in respect of the tools that are available to us; the tools, that is, that we have the ingenuity to devise.

\section{The public dimension of human thoughtfulness}

The practical problems which we as human beings face in the world today can only be solved together. Nobody, single mindedly, can solve the problem of, say, pollution, global epidemics, or world poverty. These are problems that require a shared understanding of what constitutes the problem and what might constitute possible solutions. Arendt foresaw this in her insistence that thoughtfulness is a public endeavour.

Human thoughtfulness, she argued, is a form of 'representative thinking'. Even when we are thinking on our own, we are weighing alternatives, taking on board a variety of perspectives, looking at the world from different and sometimes incommensurable points of view. Thoughtfulness, she insisted, is always deeply social, regardless of the isolated circumstances of the individual thinker.

At best, however, thoughtfulness is enacted through public dialogue. We learn to be thoughtful — to be ourselves - through interaction, transaction, and engagement. The relation between thought and language is, therefore, of paramount importance. Thought is unthinkable without the rough and tumble of human discourse. In order to think, we have to be able to listen, and to communicate.

\section{The reflexive dimension of human thoughtfulness}

So thoughtfulness is always striving for reflexivity. The thinker positions herself in relation to the thinking of others: my agency, as a thinker, is dependent upon my acknowledgement of your agency. The recognition of difference is paramount. My thoughtfulness is dependent upon my capacity to take your concerns into consideration: to grapple with them, to engage with them, and to locate myself in relation to those concerns.

This notion of reflexivity has profound implications for the way in which we conceive of professional expertise. Professional intervention is always complex, in the sense of involving dialogue, deliberation, and uncertainty of outcome. Any attempt to limit the complexity of professional intervention would, from the perspective I am here outlining, only result in de-professionalisation - in the restriction of the role of professional practitioner to that of technical operative.

That outcome is, sadly, what we are seeing across so many of the occupational groups that aspire to professionalism. Professional intervention is always complex, in the sense of being reliant upon modes of thought that take seriously the reality of human contingency and the unpredictability of human action. 
Thinking becomes more not less precise as it begins to understand its own parameters.

\section{What is theory in the context of professional understanding?}

Theory: ORIGIN late $16^{\text {th }}$ cent. (denoting a mental scheme or something to be done); via late Latin from Greek theoria 'contemplation, speculation', from theoros 'spectator'. (NOED, 1998)

So we return to the big question. But not quite. I'm much less interested in the question of what theory is in the abstract than in the question of what theory means for us as professional practitioners. I shall address the question in those more practically oriented terms. In doing so, I do not mean to suggest that the more abstract question is unimportant. It is just that I want to start from where I am and where I think you may be.

The crucial question, it seems to me, is how we use existing theory in order to theorise our own practice. I've tried to model a possible response to that question in my construction of this address. Habermas and Arendt inform my thinking, but they do not determine it. In my professional practice I find myself in dialogue with them: I test my presuppositions against the frameworks of analysis that they provide. But, equally, I question their frameworks of analysis against the often intransigent problems that I routinely confront as an academic professional. In a sense, we talk with one another across the theory-practice divide (see Nixon, 2001b).

Theory, I suggest, has three aspects that are indispensable resources for professional practitioners. Theory, in other words, faces outwards in three different directions: towards the analytical interpretation of intent and action; towards the speculative evaluation of alternative courses of action; and towards the explanatory justification of the principles underlying practice. Analytical interpretation, speculative evaluation, and explanatory justification are, to shift the metaphor, the vanishing points at which the lines of theory and practice meet in the landscape of professionalism.

\section{The analyticallinterpretive aspect of theory}

Theory has the potential capacity to provide me with the conceptual tools to read meaning and intent into our own and others' actions and the possible effects of those actions on ourselves and others. Let me give you a very simple example. I walk into an open-plan secretarial office and explain to a secretary that a particular task is urgent and requires immediate attention. At the time my overriding concern is the urgency of the task and the possible fallout from its non-completion. So, I stand over the secretary, who is of course seated, and impress upon her my mass of masculine anxieties.

Returning to my room (my space that secretaries do not presume to violate) I resume my reading of the latest book on gender theory. The conceptual appa- 
ratus that the book puts at my disposal invites me to reflect upon my previous action. I know I felt anxious, but could my action have been experienced as intimidation? I put down that particular tome and take from my shelves a well-worn text on the nature of power. Since I feel powerless, I assume that this book will console me. But instead it speaks back to me in terms of complex hierarchies of power in which my previous action might, given my relative status, be interpreted as an abuse of power.

I conclude that theory is not all it is cracked up to be. It refuses to endorse me, to underwrite my taken-for-granted assumptions about what a good person I am. It speaks back to me and challenges me at the level of personhood. At that point I either listen and hear, and in doing so engage with theory, or I put my books back where I tell myself they belong —on my dusty shelvesand I resume my cosy a-theoretical existence.

\section{The speculativelevaluative aspect of theory}

Theory, however, doesn't just give me a good bashing. It helps me pick myself up. It has the capacity, in other words, to provide me with alternative courses of action and the resources necessary to evaluate those courses of action. It helps me weigh the options. Should I do it differently next time? Should I apologise? Should I propose organisational change in respect of the mechanisms and procedures of secretarial support?

It also, crucially, helps me grapple with the problem of whether particular choices are mutually exclusive. In highlighting the need to consider underlying principles, theory may challenge what we consider to be dichotomies. It may also point-up, at the level of principle, the incompatibilities of courses of action that we have hitherto assumed to be uncomplicatedly compatible. Perhaps I should do it differently next time and apologise and seek for organisational change. Perhaps I shouldn't. Theory can help me through this moral minefield.

So, having picked me up, theory again gives me a good dusting over. It keeps on reminding me that life is not as simple as it seems; that there are other ways of thinking, other ways of doing things, other ways of being. Theory unsettles through its constant shifting of horizon; its perpetual opening up of the boundaries of possibility.

\section{The explanatory/justificatory aspect of theory}

Finally, theory helps me explain myself - to myself and others. I am not talking here about self-justification (in the pejorative sense of that term), but about the narrative unity of human agency: how, retrospectively and for all our futures, we make sense of our own and others' actions. This aspect of theory is deeply communicative in its insistence on the possibility of transparency. Having beaten us up, picked us up, and given us a second dusting-over, theory then benignly gives us the space to take stock of our own and others' actions. 
It is not insignificant, I think, that some of the most explanatory thinking of the $20^{\text {th }}$ Century was achieved by prisoners. Bonhoeffer, Gramsci, and Mandella, to name but a few, were of course the victims of variant forms of totalitarian fascism. But within the confines of their imprisonment each realised the communicative capacity of sustained theoretical explanation. Alone and isolated, except from their fellow captives, they communicated, through their commitment to explanation, an alternative vision of human capacity and the possibility of social reconstruction.

More mundane, but perhaps no less significant, are the attempts of professional practitioners to provide explanations that have a crucial bearing on future policy and practice. In seeking to explain our actions, and the principles that underpin those actions, we contribute to the legacy of human thoughtfulness. That legacy is vitally important to the task of theory building.

\section{Conclusion}

I conclude with a number of questions which, I believe, should be addressed by any member of an occupational group that aspires to professionalism:

- How can I define within my own career trajectory a space for theoretical reflection?

- How can I work with fellow practitioners, across professional boundaries, in such a way as to define that space as a common and protected space?

- How can I bring my theoretical reflections to bear on my professional relations with colleagues and clients?

- How can I communicate to wider public audiences my theoretical insights into what constitutes professional practice and the principles underpinning that practice?

I believe, from reflecting upon my own professional practice, that any attempt to address these questions leads to more open relations with both colleagues, clients, and the wider public. The questions, in other words, point us towards the notion of 'learning professions': professions the credibility and legitimacy of which is based on a principled determination to learn and to see learning as a lifelong commitment.

\section{References}

ARENDT, H. (1967). The Origins of Totalitarianism. $3^{\text {rd }}$ edn. London: Andre Deutsch. - (1968). Between Past and Future. New York: Penguin Books.

- (1998). The Human Condition. Chicago: University of Chicago Press.

Habermas, J. (2003). The Future of Human Nature. Cambridge: Polity Press.

NixON, J. (1997). «Regenerating professionalism within the academic workplace». In Broadbent, J.; Dietrich, M.; Roberts, J. (eds.). The End of the Professions? The Restructuring of Professional Work. London: Routledge, 86-103.

- (2001a). «Not without dust and heat: the moral bases of the new academic professionalism». British Journal of Educational Studies, 49, 2, 173-186. 
- (2001b). «Imagining ourselves into being: conversing with Hannah Arendt». Pedagogy, Culture and Society, 9, 2, 221-236.

- (2003). «Professional renewal as a condition of institutional change: rethinking academic work». International Studies in Sociology of Education, 13, 1, 3-15.

NiXON, J.; MARTIN, J.; MCKEOWN, P.; RANSON, S. (1997). «Towards a learning profession: changing codes of occupational practice within the 'new' management of education" British Journal of Sociology of Education, 18, 1, 5-28.

Perkin, H. (1989). The Rise of Professional Society. London: Routledge.

The New Oxford English Dictionary (1998). Oxford: Clarendon Press.

\section{Acknowledgements}

I am indebted to the hosts and organisers of the Barcelona seminar at which the original version of this paper was presented. Thanks also to fellow contributors from whom I learnt so much. 